\title{
The influence of selenium on the level of linoleic acid isomers in incubated ruminal fluid*
}

\author{
I. Wąsowska1, M. Czauderna ${ }^{1,3}$, J. Kowalczyk ${ }^{1}$ and R.J. Wallace ${ }^{2}$ \\ ${ }^{I}$ The Kielanowski Institute of Animal Physiology and Nutrition, \\ Polish Academy of Sciences \\ 05-110 Jabłonna, Poland \\ ${ }^{2}$ Rowett Research Institute, Greenburn Road \\ Bucksburn, Aberdeen, AB21 9SB, UK
}

\begin{abstract}
Ovine ruminal fluids were incubated in vitro at $39^{\circ} \mathrm{C}$ under $\mathrm{CO}_{2}$ either alone or with a combination of linoleic acid (LA) $(1.67 \mathrm{~g} / \mathrm{l})$, a low $(0.167 \mu \mathrm{g} / \mathrm{ml})$ or high $(1.67 \mu \mathrm{g} / \mathrm{ml})$ level of selenite (Se(IV)), or selenate $(\mathrm{Se}(\mathrm{VI}))$. The high level of Se(IV) resulted in a decrease of CLA isomer accumulation in in vitro incubated cultures with LA. Low and high levels of $\mathrm{Se}(\mathrm{VI})$ in ruminal fluids elevated the content of CLA isomers and trans-vaccenic acid in fluids incubated with LA.
\end{abstract}

KEY WORDS: selenate, selenite, CLA isomers, linoleic acid, linseed oil, ovine ruminal fluid

\section{INTRODUCTION}

Recent studies showed that n-3 polyunsaturated fatty acids (PUFA) and conjugated linoleic acid (CLA) isomers possess potential health benefits, such as anticarcinogenic and antidiabetogenic properties or delaying the onset of atherosclerosis. Studies indicated that dietary PUFA is directly incorporated in the rumen bacteria, isomerized to other geometric and positional isomers, metabolized into CLA isomers (Raes et al., 2004), biohydrogenated to trans-vaccenic acid and finally to stearic acid. In recent studies was found that the PUFA levels in lipids of animals and in membranes of microorganisms were positively correlated with the concentration of selenite and selenate in the diet.

Considering the above, it seemed reasonable to study the influence of selenite (Se(IV)) and selenate (Se(VI)) on the content of CLA isomers and trans-vaccenic acid (TVA; trans-9C18:1) in in vitro incubated ruminal fluids of sheep.

\footnotetext{
* Supported by the Marie Curie Training Site, 'Mass School'

${ }^{3}$ Corresponding author: e-mail: m.czauderna@ifzz.pan.pl
} 


\section{MATERIAL AND METHODS}

Eight ruminally fistulated adult sheep received a mixed diet comprising grass hay, barley, molasses, soyabean meal, and vitamins and minerals, at 500, 299.5, 100, 91 and $9.5 \mathrm{~g} / \mathrm{kg}$ dry matter, respectively, fed in equal meals of $500 \mathrm{~g}$ at 8.00 and $16.00 \mathrm{~h}$. Ruminal digesta samples were taken from each sheep before feeding in the morning, kept at $39^{\circ} \mathrm{C}$ and strained through linen cloth before use.

Linoleic acid (LA), TVA, CLA isomer methyl ester standards, sodium selenite (Se(IV)) and sodium selenate (Se(VI)) were from Sigma (UK).

Strained ruminal fluid was incubated either alone or with a combination of LA and two concentrations of $\mathrm{Se}(\mathrm{IV})$ or $\mathrm{Se}(\mathrm{VI})$. One $\mathrm{ml}$ of strained ruminal fluid was added under $\mathrm{CO}_{2}$ to tubes containing one of the following: $0.2 \mathrm{ml}$ of distilled water $\left(\mathrm{RF}_{\text {control }}\right) ; 0.1 \mathrm{ml}$ of water and $0.1 \mathrm{ml}$ of $20 \mu \mathrm{g} / \mathrm{ml} \mathrm{Se}(\mathrm{IV})$ or Se(VI) (the high Se level: Se-H; $1.67 \mu \mathrm{g} \mathrm{Se} / \mathrm{ml}$ ); $0.01 \mathrm{ml}$ of $20 \mu \mathrm{g} / \mathrm{ml} \mathrm{Se(IV)} \mathrm{or} \mathrm{Se(VI)} \mathrm{(the} \mathrm{low} \mathrm{Se}$ level: Se-L; $0.167 \mu \mathrm{g} \mathrm{Se} / \mathrm{ml}$ ); $0.1 \mathrm{ml}$ of $20 \mathrm{mg} / \mathrm{ml} \mathrm{LA}$ and $0.1 \mathrm{ml}$ of water ( $\mathrm{LA}_{\text {control }}$ ); $0.1 \mathrm{ml}$ of $20 \mathrm{mg} / \mathrm{ml} \mathrm{LA}$ and $0.1 \mathrm{ml}$ of $20 \mu \mathrm{g} / \mathrm{ml} \mathrm{Se}(\mathrm{IV})$ or Se(VI) (the high Se level); $0.1 \mathrm{ml}$ of $20 \mathrm{mg} / \mathrm{ml} \mathrm{LA}, 0.09 \mathrm{ml}$ of water and $0.01 \mathrm{ml}$ of $20 \mu \mathrm{g} / \mathrm{ml} \mathrm{Se}(\mathrm{IV})$ or Se(VI) (the low Se level). The tubes were incubated at $39^{\circ} \mathrm{C}$. All experiments were carried out on four different days using samples withdrawn from four different sheep.

The methods of hydrolysis, derivatization and fractionation were as described previously (Christie, 2003). FA-MEs were separated and quantified using a gas chromatograph (Model 6890, Agilent Technologies, UK) equipped with a FID (Wąsowska et al., 2006).

\section{RESULTS}

The influence of the low (L) and high (H) concentrations of Se(IV) and $\mathrm{Se}(\mathrm{VI})$ in ruminal fluids on the CLA isomers and TVA compositions in in vitro incubated fluids is shown in Table 1. The concentrations of all CLA isomers were usually below detection limits in incubated ruminal fluids without (RF) and with $\mathrm{Se}(\mathrm{IV})$ or $\mathrm{Se}(\mathrm{VI})$ at both concentrations. Addition of $\mathrm{Se}(\mathrm{VI})$ numerically or statistically decreased the concentrations of individual CLA isomers, as well as the sum of CLA isomers in ruminal fluids in comparison with fluid containing only LA. The higher amount of Se(IV) added to the ruminal fluids resulted in a decrease in the accumulation of CLA isomers in incubates with LA. The concentrations of formed $t 10 c 12 \mathrm{CLA}$ and $t 9 t 11 \mathrm{CLA}$ increased in fluids with LA as the duration of incubation increased, regardless of Se(IV) additions. These isomers accumulated, whereas the $c 9$ t11CLA formed during $6 \mathrm{~h}$ incubation disappeared throughout the incubations of fluids with LA regardless of $\mathrm{Se}(\mathrm{IV})$ at two levels. The $c 9 c 11$ isomer formed during $6 \mathrm{~h}$ of incubation remained almost the 
Table 1. Effects ${ }^{1}$ of two concentrations (low, L; high, H) of Se(IV) and $\mathrm{Se}(\mathrm{VI})$ on the concentration of CLA isomers and trans-vaccenic acid (TVA) $(\mu \mathrm{g} / \mathrm{ml})$ in incubated ruminal fluids $\left(\mathrm{RF}_{\text {control }}\right)$

\begin{tabular}{|c|c|c|c|c|c|c|c|c|c|c|c|c|c|}
\hline \multirow{3}{*}{ ڤે } & \multirow{3}{*}{ 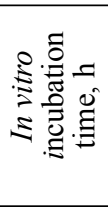 } & \multirow{2}{*}{\multicolumn{2}{|c|}{ TVA }} & \multicolumn{8}{|c|}{ CLA isomers } & \multirow{2}{*}{\multicolumn{2}{|c|}{$\begin{array}{l}\text { Sum of all } \\
\text { CLA } \\
\text { isomers }\end{array}$}} \\
\hline & & & & $\underset{a}{a}$ & $\frac{2}{0}$ & $\underset{a}{\grave{J}}$ & $\bar{a}$ & $\underset{a}{a}$ & $\frac{1}{2}$ & $\underset{\Xi}{\bar{\Xi}}$ & $\bar{\Xi}$ & & \\
\hline & & $\overline{\mathrm{Se}(\mathrm{IV})}$ & $\mathrm{Se}(\mathrm{VI})$ & \multicolumn{2}{|c|}{ Additive: } & \multicolumn{2}{|c|}{$\mathrm{Se}(\mathrm{IV})$} & \multicolumn{2}{|c|}{ Additive: } & \multicolumn{2}{|c|}{$\mathrm{Se}(\mathrm{VI})$} & \multicolumn{2}{|c|}{$\mathrm{Se}(\mathrm{IV}) \mathrm{Se}(\mathrm{VI})$} \\
\hline $\mathrm{RF}_{\text {(ntrol }}$ & 0 & 13 & 13 & 0 & 0 & 0 & 0 & 0 & 0 & 0 & 0 & 0 & 0 \\
\hline $\mathrm{Se}-\mathrm{L}$ & 0 & 15 & 15 & 0 & 0 & 0 & 0 & 0 & 0 & 0 & 0 & 0 & 0 \\
\hline $\mathrm{Se}-\mathrm{H}$ & 0 & 14 & 14 & 0 & 0 & 0 & 0 & 0 & 0 & 0 & 0 & 0 & 0 \\
\hline LA & 0 & 14 & 14 & 4 & 1.5 & 0 & $0.5^{\mathrm{a}}$ & 4 & 1.5 & 0 & 0.5 & 6 & 6 \\
\hline LASe-L & 0 & 14 & 13 & 2.9 & 0.7 & 0 & 0.5 & 2.4 & 0 & 0 & 0 & 4 & 2.4 \\
\hline LASe-H & 0 & 17 & 13 & 3.4 & 0.9 & 0.6 & $2.1^{\mathrm{a}}$ & 3.6 & 1.2 & 0 & 0.5 & 7 & 0 \\
\hline $\mathrm{RF}_{\mathrm{c}}$ & 6 & $15^{\mathrm{a}}$ & $15^{\mathrm{a}}$ & 0 & 0 & 0 & 0 & 0 & 0 & 0 & 0 & 0 & 0 \\
\hline $\mathrm{Se}-\mathrm{L}$ & 6 & 14 & 14 & 0 & 0 & 0 & 0 & 0 & 0 & 0 & 0 & 0 & 0 \\
\hline $\mathrm{Se}-\mathrm{H}$ & 6 & 14 & 14 & 0 & 0 & 0 & 0 & 0 & 0 & 0 & 0 & 0 & 0 \\
\hline LA & 6 & $48^{\mathrm{ab}}$ & $48^{\mathrm{a}}$ & $285^{\mathrm{a}}$ & $37^{\mathrm{ab}}$ & $18^{\mathrm{a}}$ & $45^{\mathrm{a}}$ & 285 & 37 & 18 & 45 & $385^{\mathrm{a}}$ & 386 \\
\hline LASe-L & 6 & 33 & 42 & 238 & $26^{\mathrm{b}}$ & 14 & 32 & 281 & 31 & 16 & 43 & 309 & 370 \\
\hline LASe-H & 6 & $33^{\mathrm{b}}$ & 51 & $229^{a}$ & $21^{\mathrm{a}}$ & $13^{\mathrm{a}}$ & $35^{\mathrm{a}}$ & 257 & 43 & 16 & 46 & $298^{\mathrm{a}}$ & 362 \\
\hline $\mathrm{RF}_{\text {control }}$ & 12 & $20^{\mathrm{a}}$ & $20^{\mathrm{a}}$ & 0 & 0 & 0 & 0 & 0 & 0 & 0 & 0 & 0 & 0 \\
\hline $\mathrm{Se}-\mathrm{L}$ & 12 & 18 & 19 & 1 & 0 & 0 & 0.5 & 0.7 & 0 & 0 & 0.5 & 1.5 & 1.2 \\
\hline Se-H & 12 & 19 & 18 & 0.7 & 0 & 0 & 0.6 & 0 & 0 & 0 & 0 & 1.3 & 0 \\
\hline $\mathrm{LA}_{\text {control }}$ & 12 & $198^{\mathrm{a}}$ & $198^{\mathrm{a}}$ & 230 & $62^{\mathrm{a}}$ & 22 & 70 & 230 & 62 & 22 & 70 & 384 & 384 \\
\hline LASe-L & 12 & 101 & 162 & 207 & 38 & 15 & 44 & 260 & 61 & 22 & 72 & 305 & 415 \\
\hline LASe-H & 12 & 94 & 170 & 154 & $26^{a}$ & 14 & 51 & 266 & 60 & 22 & 67 & 245 & 415 \\
\hline $\mathrm{RF}_{\text {control }}$ & 18 & $19^{\mathrm{a}}$ & $19^{a}$ & 0 & 0 & 0 & 0 & 0 & 0 & 0 & 0 & 0 & 0 \\
\hline $\mathrm{Se}-\mathrm{L}$ & 18 & 19 & 18 & 0 & 0 & 0 & 0 & 0 & 0 & 0 & 0.5 & 0 & 0.5 \\
\hline $\mathrm{Se}-\mathrm{H}$ & 18 & 18 & 21 & 0 & 0 & 0 & 0 & 0 & 0 & 0 & 0 & 0 & 0 \\
\hline $\mathrm{LA}_{\text {control }}$ & 18 & $446^{\mathrm{a}}$ & $446^{\mathrm{a}}$ & 171 & 70 & 17 & 82 & 171 & 70 & 17 & 82 & $339^{a}$ & 339 \\
\hline LASe-L & 18 & 334 & 448 & 165 & 80 & 14 & 67 & 134 & 67 & 15 & 79 & 325 & 295 \\
\hline LASe-H & 18 & 287 & 375 & 100 & 53 & 13 & 52 & 168 & 71 & 18 & 87 & $217^{\mathrm{a}}$ & 344 \\
\hline $\mathrm{RF}_{\text {contr }}$ & 24 & $18^{\mathrm{a}}$ & $18^{\mathrm{a}}$ & 0 & 0 & 0 & 0 & 0 & 0 & 0 & 0 & 0 & 0 \\
\hline $\mathrm{Se}-\mathrm{L}$ & 24 & 15 & 17 & 0 & 0 & 0 & 0 & 0 & 0 & 0 & 0 & 0 & 0 \\
\hline $\mathrm{Se}-\mathrm{H}$ & 24 & 18 & 20 & 0 & 0 & 0 & 0 & 0 & 0 & 0 & 0 & 0 & 0 \\
\hline $\mathrm{LA}_{\text {control }}$ & 24 & $618^{\mathrm{a}}$ & $618^{\mathrm{a}}$ & 85 & 55 & 22 & $79^{\mathrm{a}}$ & 85 & 55 & 22 & 79 & 241 & 241 \\
\hline LASe-L & 24 & 564 & 552 & 76 & 66 & 8 & $46^{\mathrm{a}}$ & 121 & 85 & 14 & 94 & 196 & 315 \\
\hline LASe-H & 24 & 446 & 491 & 75 & 77 & 8 & 57 & 132 & 81 & 19 & 99 & 217 & 332 \\
\hline
\end{tabular}

${ }^{1}$ means in columns at the same incubation time with the same letter are significantly different at ${ }^{\mathrm{a}, \mathrm{b}} \mathrm{P}<0.05$ or at ${ }^{\mathrm{A}, \mathrm{B}} \mathrm{P}<0.01 ; t, c$ - abbreviation for geometrical form: trans, cis, respectively

same as in ruminal fluid with LA until $24 \mathrm{~h}$, whereas both levels of Se(IV) in fluids with LA slightly reduced the content of $c 9 c 11 \mathrm{CLA}$ after $18 \mathrm{~h}$ incubation.

The influence of two levels of Se(IV) on the concentration of TVA in incubates with LA was similar to the effect of accumulation of c9t11CLA. However, a tendency or statistical increase of the decrement of the TVA concentration was observed with increasing the concentration of Se(IV) in ruminal fluids with LA. 
To test the differential effects of Se(IV) and Se (VI) on the metabolism of LA and CLA isomer formation and their disappearance rate in ruminal fluids, Se(VI) was incubated in fluids with LA. The effects of low and high levels of Se(VI) on CLA isomer accumulation differed from the influence of Se(IV) on the abundance of CLA isomers in rumen fluids. Se(VI) numerically stimulated formation of c9t11CLA, $t 10 c 12$ CLA and $t 9 t 11$ CLA in incubates with LA after $24 \mathrm{~h}$ incubation. The high level of Se(VI) usually more effectively promoted the accumulation of these CLA isomers and the sum of all CLA isomers in incubates with LA. No effect of either level of $\mathrm{Se}(\mathrm{VI})$ was noticed on the content of $c 9 c 11 \mathrm{CLA}$ in incubates with LA. Se(VI) numerically lowered the rate of LA metabolism, in addition, disappearance of LA decreased as the level of $\mathrm{Se}(\mathrm{VI})$ increased. The content of TVA in incubated ruminal fluids is also numerically lower in fluids with $\mathrm{Se}(\mathrm{VI})$ and the high level of $\mathrm{Se}(\mathrm{VI})$ resulted in the lowest accumulation of TVA.

\section{CONCLUSIONS}

Addition of $\mathrm{Se}(\mathrm{VI})$ elevated the concentration of CLA isomers and TVA in incubated ruminal fluids with LA. We hypothesise that $\mathrm{Se}(\mathrm{VI})$ is preferentially biohydrogenated by ruminal bacteria and the reduction of $\mathrm{Se}$ (VI) to $\mathrm{Se}(\mathrm{IV})$ competes with the reduction of double bonds of CLA isomers and other unsaturated fatty acids. Therefore, we could suggest that feeding Se(VI) and LA can improve the nutritive value of products derived from ruminants. In particular, meat, milk and dairy products should contain more CLA isomers derived from ruminal digesta, as well as from endogenous synthesis of conjugated dienes from TVA or trans-7C18:1.

\section{REFERENCES}

Christie W.W., 2003. Lipid Analysis. Isolation, Separation, Identification and Structural Analysis of Lipids. The Oily Press Bridgwater (England)

Raes K., De Smet S., Demeyer D., 2004. Effect of dietary fatty acids on incorporation of long chain polyunsaturated fatty acids and conjugated linoleic acid in lamb, beef and pork meat: a review. Anim. Feed Sci. Tech. 113, 199-221

Wąsowska I., Maia M.R.G., Niedźwiedzka K.M., Czauderna M., Ramalho Ribero J.M.C., Devillard E., Shingfield K.J., Wallace R.J., 2006. Influence of fish oil on ruminal biohydrogenation of C18 unsaturated fatty acids. Brit. J. Nutr. 95, 1199-1211 